\title{
Effect of some chemicals on incidence of poato soft rot disease in Bangladesh
}

\author{
M. M. Rahman ${ }^{1 *}$, A. A. Khan ${ }^{2}$, I. H. Mian ${ }^{2}$, A. M. Akanda ${ }^{2}$ and M. Z. Alam ${ }^{3}$ \\ 1 Bangladesh Jute Research Institute, Dhaka \\ 2 Department of Plant Pathology, Bangabandhu Sheikh Mujibur Rahman Agricultural University, Gazipur-1706, Bangladesh \\ 3 Department of Entomology, Bangabandhu Sheikh Mujibur Rahman Agricultural University, Gazipur-1706, Bangladesh
}

\begin{abstract}
Bactericidal effect was investigated by chemicals against potato soft rot bacteria in vitro and in storage. The chemicals were acetic acid, boric acid, bleaching powder, lactic acid, calcium hydroxide, calcium chloride, potassium chloride and sodium hypo-chloride. Among eight chemicals only three chemicals viz. acetic acid, boric acid and bleaching powder showed bactericidal activity against potato soft rot bacteria Pectobacterium carotovorum subsp. carotovorum (E. carotovora subsp. carotovora) P-138 in vitro. Based on the results of in vitro experiment three chemicals, acetic acid, boric acid and bleaching powder were used to control soft rot disease of potato in storage. Fresh potato tubers were dipped in $0.2 \%$ solution/suspensions of acetic acid, boric acid and bleaching powder for $30 \mathrm{~min}$. Then soft rot bacteria Pectobacterium carotovorum subsp. carotovorum P-138 was inoculated on potato. Finally potatoes were stored for 22 weeks in net bags in sterilized condition. All the three chemicals significantly decreased the infection rate, loss in weight and increased percentage of disease reduction (PDR) of potato. Boric acid was the most effective in controlling the soft rot disease of potato in storage followed by acetic acid and bleaching powder. So these chemicals may be used for seed purpose storage of potato tubers for year round storage at farmer's level.
\end{abstract}

Key words: Chemicals; Control; Soft rot racteria; Potato

\section{Introduction}

Soft rot is a common and serious post harvest problem of potato tubers. The disease causes severe losses of the crop in storage (Bdliya and Haruna, 2007). Normally chemicals are not recommended for the control of soft rot disease (Agrios, 1997) because of high risk of residual effect on health. However, many scientists tested various chemicals including bactericides and microbial pesticides to control the soft rot bacteria (Chen and Lin 2000; Abd-El-Khair 2004; Wright et al., 2005). A number of compounds with antimicrobial activity are identified, which increase resistance in potato against soft rot bacteria (Hammerschmidt and Smith, 1997). From these compounds benzothiodiazole (BTH) which induces systemic resistance in many plants and effective against various plant pathogens (Gorlach et al., 1996; Bokshi et al., 2003). Increased resistance in potato tubers against Pectobacterium carotovorum subsp. carotovorum was observed when tubers were dipped in acetyl salicylic acid (ASA) (Abd-El-Sayed et al., 1996; Bokshi et al., 2003). Salt treatments can inhibit plant pathogens or suppress their toxin production (Olivier et al., 1998). Salts including calcium propionate and calcium chloride reduced tissue maceration of potato tubers caused by E. carotovora (McGuire and Kelman, 1986; Biggs et al., 1997; Droby et al., 1997). Suppression of bacterial soft rot in potato tubers by application of an antibiotic kasugamycin was investigated by Bartz (1999). Use of chemicals free from health hazards may be an effective and acceptable control measures against soft rot bacteria of potato if available. So, search for such chemicals is necessary. Considering the above facts the present investigation was undertaken to test some chemicals for their effectiveness to control soft rot bacteria of potato tubers.

\section{Materials and methods}

In vitro evaluation of eight chemicals against soft rot bacteria

An in vitro test experiment was conducted to evaluate eight chemicals for their bactericidal activity against soft rot bacteria of potato (Pectobacterium carotovorum subsp. carotovorum P-138). The chemicals were acetic acid, boric acid, bleaching powder, lactic acid, calcium hydroxide, calcium chloride, potassium chloride and sodium hypo-chloride. Acetic acid, boric acid, lactic acid, bleaching powder and sodium hypo-chloride were used at $0.02 \%, 0.05 \%, 0.10 \%$. Rests of the chemicals were used at $0.05,0.10$ and $0.20 \%(\mathrm{w} / \mathrm{w})$.

\footnotetext{
* Corresponding author e-mail: majibar_rhmn@yahoo.com
} 
A standard bacterial growth medium Yeast Peptone Dextrose Agar (YPDA) was prepared. After cooking the medium was amended with each chemical. Required amount of each chemical was added to YPDA and mixed thoroughly. The amended medium was autoclaved for $20 \mathrm{~min}$ at $121^{\circ} \mathrm{C}$ under $1.1 \mathrm{~kg} / \mathrm{cm}^{2}$ pressures. The medium was poured in petri dishes at $20 \mathrm{ml} /$ plate and allowed to solidify.

To prepare the inocula of soft rot bacteria of potato, Pectobacterium carotovorum subsp. carotovorum P-138 were grown on YPDA at $28^{\circ} \mathrm{C}$ for $24 \mathrm{~h}$. Bacterial cells were collected from the culture and suspended in sterilized distilled water to a concentration of ca $10^{8} \mathrm{cfu} / \mathrm{ml}$.

After solidification of YPDA with the chemicals, the plates were spot inoculated and incubated at $30^{\circ} \mathrm{C}$ in an incubator. The plates were arranged in the incubator following completely randomized design with three replications. Three additional plates without any chemical were maintained, which served as control. Growth of the test bacteria was observed up to 14 days of inoculation and antibacterial activity of the chemicals was determined.

Efficacy of the chemicals to control soft rot of potato in storage

Based on the results of the in vitro test, three chemicals namely acetic acid, boric acid, and bleaching powder were selected to test their efficacy to control soft rot disease of potato in storage condition. Three potato varieties viz. Cardinal, Diamant and Granola were used in the experiment. For treatment, fresh potato tubers of each variety were dipped in $0.2 \%$ solution of acetic acid, boric acid and bleaching powder individually for $30 \mathrm{~min}$ prior to inoculation with soft rot bacteria of potato (Pectobacterium carotovorum subsp. carotovorum P-138). After dipping, potato tubers were air dried at room temperature.

Fresh cultures of soft rot bacteria grown on YPDA were suspended in sterilized distilled water $\left(\mathrm{ca} .10^{8} \mathrm{cfu} / \mathrm{ml}\right)$ to prepare inocula. Chemically treated potatoes were inoculated with the inoculum suspensions of respective bacteria with an automizer. Inoculated potato tubers were air dried again at room temperature and packed in net bags and stored at room temperature for 22 weeks in sterilized condition. Untreated control was maintained for each variety, which was inoculated with the pathogen but not treated with any chemical. The tubers were checked on 2, 6, 10, 14, 18 and 22 weeks after inoculation and data on soft rot infection and loss of weight due to soft rot in storage were recorded and expressed as percentage using the following formula (Abd-El-Khair and Karima, 2007).

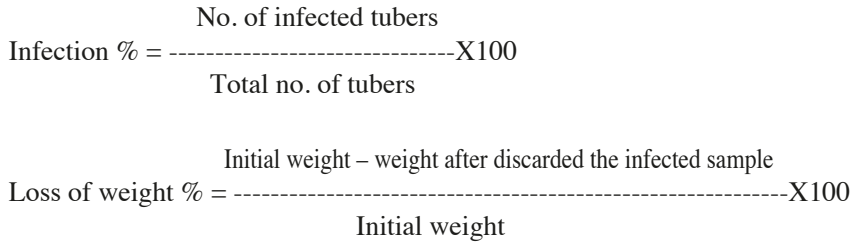

Percentage of disease reduction (PDR) was calculated following formula shown below (Hajhamed et al., 2007):

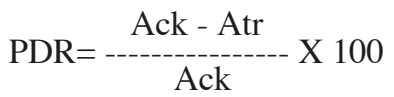

Where, Ack = loss in weight in control and Atr = loss in weight in treatment.

\section{Results and discussion}

In vitro evaluation of eight chemicals against soft rot bacteria

Among the eight chemicals tested in the experiment, only acetic acid, boric acid and bleaching powder showed antibacterial activity against indicator soft rot bacteria (Pectobacterium carotovorum subsp. carotovorum P-138) (Table I and Fig. 1). The growth of the two indicator bacteria completely inhibited in case of three chemicals at their higher concentration $(0.10 \%)$. At a concentration of $0.05 \%$, acetic acid and boric acid also inhibited the growth of the indicator bacteria considerably. Laboratory evaluation of these three chemicals has given encouraging results, indicating their potential in the control of potato soft rot bacterial disease. Based on the results of this in vitro test, these three chemicals were selected for treatment of potato tubers to control soft rot disease of potato in storage.

\section{Efficacy of chemicals to control soft rot of potato in storage}

Application of the chemicals significantly decreased the percentage of infection (Fig. 2), loss (in weight) (Fig. 3), and increased the percentage of disease reduction (PDR) (Fig. 4) of potato soft rot compared to control. Mean infection percentage of three potato varieties was lowest in case of boric acid treatment, which was followed by acetic acid and bleaching powder. In case of percentage of loss in weight, similar trend was found as infection percentage. The lowest infection percentage, lowest loss in weight and highest reduction of disease were found in the variety Granola while the highest infection percentage, highest loss in weight and lowest reduction of disease were found in the variety Cardinal under all chemical treatments during the storage period of 22 weeks. In untreated control, infection percentages were much higher than treated ones and $100 \%$ potato tubers were damaged within 14 weeks of storage (Fig. 2 and 3). 
Table I. Antibacterial activity of acetic acid, boric acid and bleaching powder against soft rot bacteria of potato (Pectobacterium carotovorum subsp. carotovorum P-138) in vitro

\begin{tabular}{|c|c|}
\hline \multirow[t]{2}{*}{ Concentration } & Antibacterial activity of acetic acid \\
\hline & $\begin{array}{l}\text { Pectobacterium carotovorum subsp. carotovorum P-138 } \\
\text { (Potato soft rot bacteria) }\end{array}$ \\
\hline $0.02(\%)$ & - \\
\hline $0.05(\%)$ & + \\
\hline $0.10(\%)$ & + \\
\hline Control* & - \\
\hline \multirow[t]{2}{*}{ Concentration } & Antibacterial activity of boric acid \\
\hline & $\begin{array}{l}\text { Pectobacterium carotovorum subsp. carotovorum P-138 } \\
\text { (Potato soft rot bacteria) }\end{array}$ \\
\hline \multicolumn{2}{|l|}{$0.02(\%)$} \\
\hline $0.05(\%)$ & + \\
\hline $0.10(\%)$ & + \\
\hline Control* & - \\
\hline
\end{tabular}

\begin{tabular}{|c|c|}
\hline \multirow[t]{2}{*}{ Concentration } & Antibacterial activity of bleaching powder \\
\hline & $\begin{array}{l}\text { Pectobacterium carotovorum subsp. carotovorum P-138 } \\
\text { (Potato soft rot bacteria) }\end{array}$ \\
\hline \multicolumn{2}{|l|}{$0.02(\%)$} \\
\hline $0.05(\%)$ & - \\
\hline $0.10(\%)$ & + \\
\hline Control* & - \\
\hline
\end{tabular}

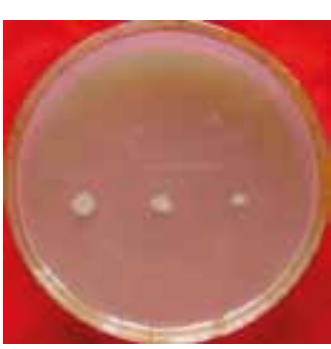

A $(0.02 \%)$

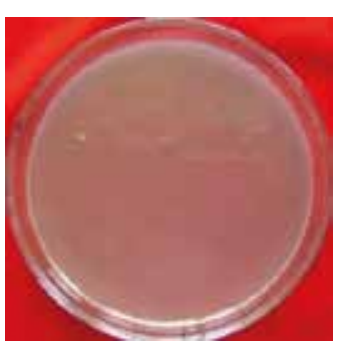

B $(0.05 \%)$

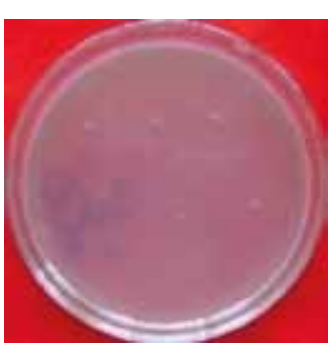

C $(0.10 \%)$

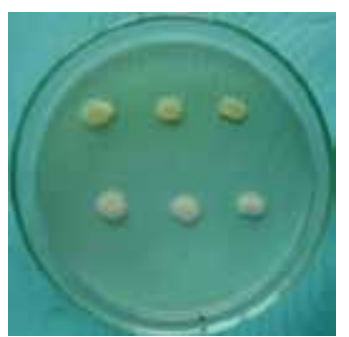

D Control

Fig. 1. In vitro antibacterial activity of boric acid against soft rot bacteria of potato (E. carotovora subsp. carotovora P-138); D-control (no chemical used) 


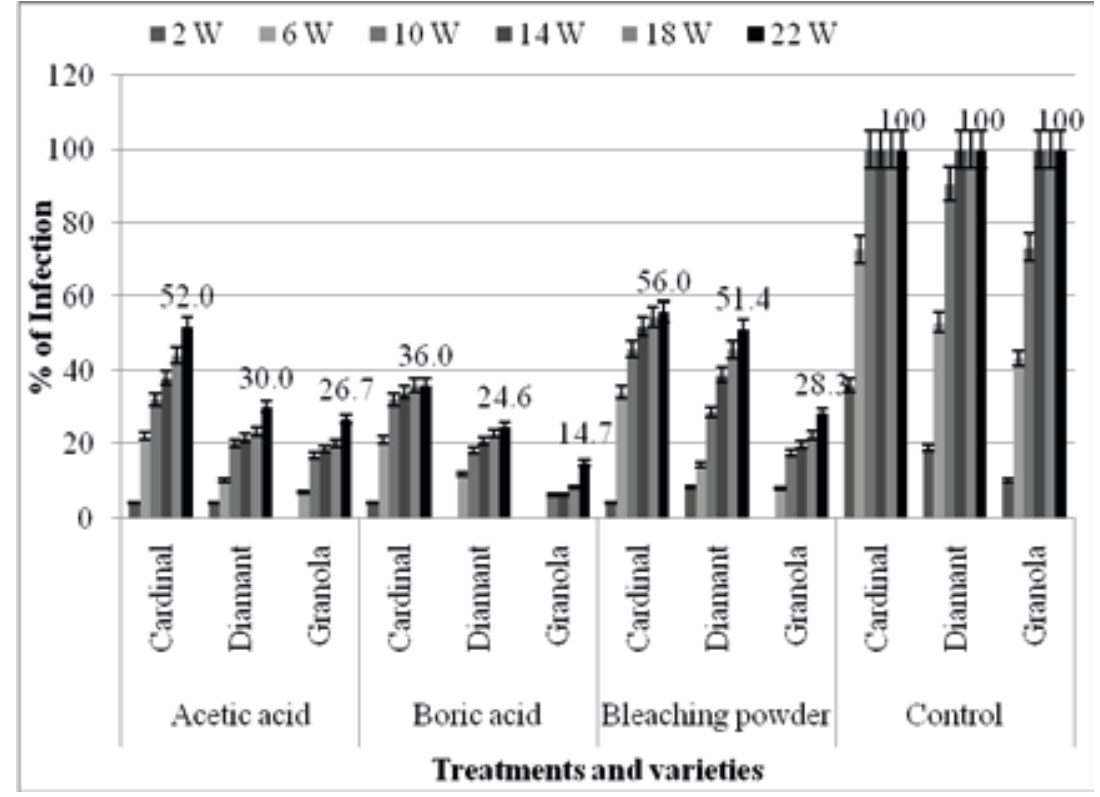

Fig. 2. Effect of three chemical treatments on soft rot incidence of potato in storage at 4 weeks $(W)$ interval

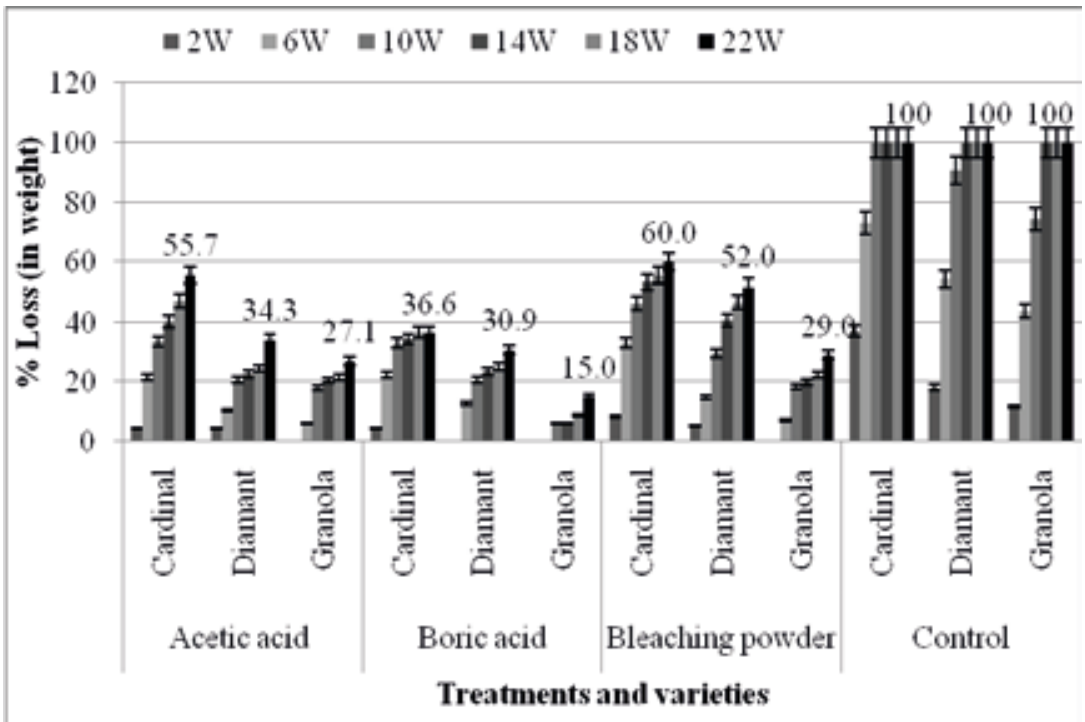

Fig. 3. Effect of three chemical treatments on percentage of loss in weight of potato in storage at 4 weeks $(W)$ interval

Among three treatments boric acid was most effective to control the potato soft rot in storage followed by acetic acid and bleaching powder. Therefore, the use of chemicals for the control of potato soft rot bacteria prevented the initial infection and multiplication of soft rot pathogens.
The results of the present investigation revealed that three chemicals viz. acetic acid, boric acid and bleaching powder showed bactericidal activity against potato soft rot bacteria Pectobacterium carotovorum subsp. carotovorum (E. carotovora subsp. carotovora) P-138 in vitro and they were effective in controlling soft rot disease of potato in storage 
condition. In our experiment, boric acid performed best in controlling potato soft rot disease in storage. So the chemicals may be used for seed purpose storage of potato tubers for year round storage at farmer's level in Bangladesh. This is the first report in Bangladesh for controlling soft rot disease of potato. carotovorum subsp. carotovorum $\mathrm{P}-138$ in vitro. Boric acid performed best in controlling potato soft rot disease in storage. So the chemicals may be used for seed purpose storage of potato tubers for year round storage at farmer's level in Bangladesh.

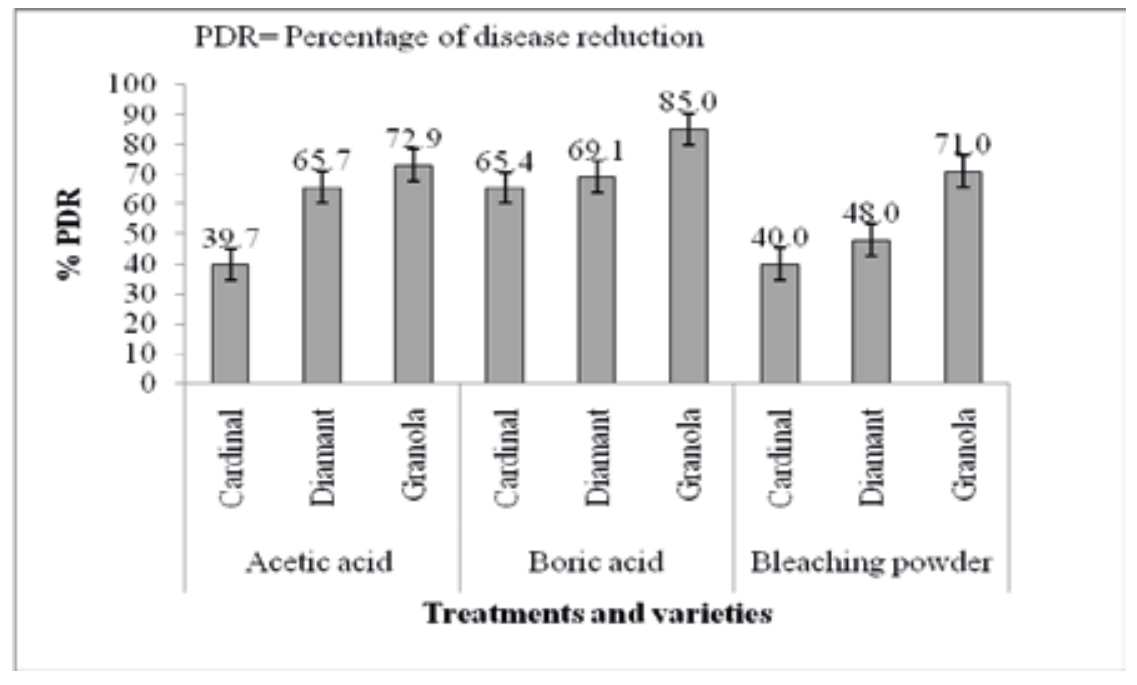

Fig. 4. Effect of three chemical treatments on percentage of disease reduction (PDR) of potato in storage condition at 22 week $(W)$ of storage

Many researchers also reported that some chemicals are effective in controlling soft rot disease. Hajhamed et al. (2007) applied potassium sulfate, ammonium phosphate and calcium chloride as salt compounds significantly decreased severity of bacterial soft rot disease of potato. Saleh and Huang (1997) reported that benzoic acid and sodium benzoate at 1,5 and $10 \mathrm{mM}$ inhibited soft rot bacterial growth and were effective in controlling the disease in both tomato fruits and potato tubers. Salts including calcium propionate and calcium chloride reduced tissue maceration of potato tubers caused by E. carotovora (McGuire and Kelman, 1986; Biggs et al., 1997; Droby et al., 1997; Olivier et al., 1998). Reduction of soft rot infection when treated with chemicals was possibly due to acidic solution of the chemicals and bactericidal activities. However, mechanism of the chemical compounds and their harmful activities remained to be determined. In addition, phytotoxicity and the environmental effects of the chemicals on epiphytic beneficial microorganisms need to be addressed before transfer the technology to farmers.

\section{Conclusion}

Acetic acid, boric acid and bleaching powder showed bactericidal activity against soft rot bacteria, Pectobacterium

\section{Acknowledgement}

The authors are grateful to Ministry of Science and Information \& Communication Technology, Bangladesh, for assistance by providing (NSICT) fellowship to conduct the study smoothly.

\section{References}

Abd El-Sayed, Wafaa M, Abd El-Ghaffar NY and Shehata AM (1996), Application of salicylic acid and aspirin for induction of resistance to tomato plants against bacterial wilt and its effect on endogenous hormones, Ann. Agric. Sci. 41: 1007-1020.

Abd-El-Khair H (2004), Efficacy of starner in controlling the bacterial soft rot in onion, Ann. Agril. Sci. 49(2): 721-731.

Abd-El-Khair H and Karima HEH (2007), Application of some bactericides and bioagents for controlling the soft rot disease in potato, Res. J. Agric. and Bio. Sci. 3(5): 463-473.

Agrios GN (1997), Control of plant diseases. In: Plant Pathology, $4^{\text {th }}$ Ed., Academic Press, California, pp 200-216. 
Bartz JA (1999), Suppression of bacterial soft rot in potato tubers by application of kasugamycin, American $J$. Potato Res. 76(3): 127-136.

Bdliya BS and Haruna HU (2007), Efficacy of solar heat in the control of bacterial soft of potato tubers caused by Erwinia carotovora subsp. carotovora, J. Plant Protec. Res. 47: 1 .

Biggs AR, El-Kholi MM, El-Neshawy S and Nickerson R (1997), Effect of calcium salts on growth, polygalacturonase activity, and infection of peach Fruit by Monilinia fructicola, Plant Dis. 81: 399-403.

Bokshi AI, Morris SC and Deverall BJ (2003), Effects of benzothiadiazole and acetylsalicylic acid on b-1, 3 -glucanase activity and disease resistance in potato, $J$. Plant Pathol. 52: 22-27.

Chen CW and Lin CY (2000), Control of Erwinia soft rot disease of Calla lily, Plant Pathology Bulletin 9(3): 107-114.

Droby S, Wisniewski ME, Cohen L, Weiss B, Touitou D, Eilam Y and Chalutz E (1997), Influence of $\mathrm{CaCl}_{2}$ on Penicillium digitatum grapefruit peel tissue and biocontrol activity of Pichia guilliermondii, Plant Dis. 87: $310-315$.

Gorlach J, Sandra V, Gertrud K, Georges H, Uli B, Karl-Heinz K, Oostendrop M, Staub T, Ward E, Kessmann H and Rayals J (1996), Benzothiadiazole, a novel class of inducers of systemic acquired resistance in wheat, Plant cell 8: 629-643.
Hajhamed AA, Sayed WMAE, Yazied AAE and Ghaffar NYAE (2007), Suppression of Bacterial Soft Rot Disease of Potato, Egypt J. Phytopathol. 35(2): 69-80.

Hammerschmidt R and Smith JB (1997), Acquired resistance to disease in plants, Hort. Rev. 18: 247-289.

McGuire RG. and Kelman A (1986), Calcium in potato cell wall in relation to tissue maceration by Erwinia carotovora, Phytopathology 76: 401-406.

Olivier C, Halseth DE, Mizubuti ESG and Loria R (1998), Postharvest application of organic and inorganic salts for suppression of silver scurf on potato tubers, Plant Dis. 82: 213-217.

Saleh OI and Huang JS (1997), Bacterial soft rot disease of tomato fruits in Florida, USA: Identification, response of some American and Egyptian cultivars of solanaceous plants and chemical control, Assiut $J$. Agril. Sci. 28(2): 11-26.

Wright PJ, Triggs CM and Burge GK (2005), Control of bacterial soft rot in calla (Zantedeschia spp.) by pathogen exclusion, elimination and removal, New-Zealand J. Crop and Hort. Sci. 33(2): 117-123.

Received: 16 August 2016; Revised: 30 November 2016; Accepted: 28 December 2016. 